\title{
HEPATITIS C PATIENTS FROM WEST REGION OF MINAS GERAIS STATE, BRAZIL: SATISFACTION WITH DENTAL CARE PROVIDED BY SPECIALIZED SERVICE
}

\author{
PACIENTES COM HEPATITE C DA REGIÃO OESTE DE MINAS GERAIS, BRASIL: \\ SATISFAÇÃO COM O ATENDIMENTO ODONTOLÓGICO OFERECIDO PELO \\ SERVIÇO ESPECIALIZADO
}

\section{Cléa Adas Saliba GARBIN¹; Neila Paula de SOUZA²; Artênio José Ísper GARBIN³; Suzely Adas Saliba MOIMAZ ${ }^{4}$}

1. Full Professor and vice-coordinator, Preventive and Social Dentistry Post-graduation Program, Universidade Estadual Paulista Unesp, Araçatuba, SP, Brazil; 2. Master Degree and PhD Student, Preventive and Social Dentistry Post-graduation Program, Universidade Estadual Paulista - Unesp, Araçatuba, SP, Brazil, neilapsouza@ hotmail.com, Brazil; 3. Adjunct Professor, Preventive and Social Dentistry Post-graduation Program, Univ. Estadual Paulista - Unesp, Araçatuba, SP, Brazil; 4. Full Professor and coordinator, Preventive and Social Dentistry Post-graduation Program, Universidade Estadual Paulista - Unesp, Araçatuba, SP, Brazil.

\begin{abstract}
Hepatitis C virus (HCV) infection is a worldwide health public problem, affecting over 123 million people. HCV infected individuals should have access to dental services, even those who are liver transplant candidates or who are undergoing medical treatment. It is also important that they are pleased with the service offered. Objective: Characterize the patients infected by HCV and verify their satisfaction with dental care in comparison to non infected individuals. Methods: A cross-sectional survey was carried out on 170 individuals, divided into two groups, HCV infected group (85 individuals) and non-infected group (85 individuals). Participants answered a questionnaire about their demographic data, risk factors, accessibility and satisfaction with dental service. Results: HCV infected group had lower education level, having only $30.6 \%$ finished pre-school. Considering sexual orientation, $70.6 \%$ of HCV infected group was heterosexual and 92.9\% had one regular sexual partner. Sixty- five HCV infected individuals (77.4\%) and 72 non-infected $(85.7 \%)$ reported not using condoms during sexual intercourse. Forty-two percent of HCV infected group and $61.2 \%$ of non-infected group were satisfied with dental service. At multivariate analysis, education level was risk variable. Conclusion: Education level was a risk factor to HCV infection and HCV infected patients showed lower frequency of satisfaction with dental services.
\end{abstract}

KEYWORDS: Hepacivirus. Hepatitis C. Oral health. Risk factors. Personal satisfaction.

\section{INTRODUCTION}

Hepatitis $\mathrm{C}$ is a hepatotropic viral infection caused by hepatitis $\mathrm{C}$ virus (HCV). It is a serious public health problem and the main cause of chronic hepatic disease, cirrhosis, hepatic cells carcinoma and liver transplants (HAJARIZADEH; GREBELY; DORE, 2013; QIU; OZAWA, TERASAKI, 2005).

$\mathrm{HCV}$ virus is transmitted mainly by parenteral route. Thus, risks factors are transfusion of contaminated blood or blood products; organ, tissue and bone marrow transplants from $\mathrm{HCV}$ infected donors, administration of unsafe therapeutic injections, occupational exposure to contaminated blood, child-birth to HCV-infected mother and unsafe intercourse with someone infected by HCV. In the latter half of the 20th century, illicit injection drug use is the major risk factor responsible for the rapid spread of hepatitis $\mathrm{C}$ virus (HCV) infection (ALTER, 2007; MOHSEN et al., 2015).

Over the last 15 years, estimates indicates an increase in HCV infection from $2.3 \%$ to $2.8 \%$, i.e. between 123 million and 170 million people are infected with HCV worldwide (MOHD HANAFIAH et al., 2013). Increasing levels of diagnosis and treatment access improved life expectancy of $\mathrm{HCV}$ infected individuals, resulting in an increase on the demand for health care services (GREBELY; DORE, 2011).

Brazil has a free program considered a global reference for care of $\mathrm{HCV}$ infected individuals named "National Program to Prevent and Control Viral Hepatitis" (NPVH). Its purpose is to: develop actions concerning health promotion, prevention and assistance to patients; reinforce the epidemiological and healthy surveillance; organize, regulate, monitor and evaluate all the health actions; expand the accessibility and improve the quality of health services offered by multidisciplinary teams (BRAZIL, 2005).

A dentist is a member of multidisciplinary team and has legal obligation to offer dental care for any patient, including patients with infectious diseases, such as Hepatitis C. According to Brazilian Code of Dental Ethics "It is ethical breach to discriminate any individual through any form or 
under any excuse". Consequently, to recuse dental attendance because of $\mathrm{HCV}$ infection is considered as discrimination against someone (FEDERAL COUNCIL OF DENTISTRY, 2012).

Up to $74 \%$ of HCV infected individuals can develop extra-hepatic manifestations during the course of hepatitis C (GALOSSI et al., 2007). Some of these manifestations can cause oral problems in salivary glands, tongue, mucous and cutaneous diseases; these conditions require special care during dental procedures (GARBIN et al., 2014; STOOPLER et al., 2014).

HCV infected individuals should have access to dental services, even those who are liver transplant candidates or who are undergoing medical treatment (DOUGALL; FISKE, 2008; NAGAO; SATA, 2010). It is also important that they are pleased with the service offered.

No matter the stage of the liver disease, preventive and educational dental procedures should be performed, such as orientation about oral hygiene and diet, prophylaxis and topical use of fluoride. $\mathrm{HCV}$ infected individuals present high risk of dental caries due to decreased salivary flow and also high risk of periodontal disease due to deficient oral hygiene, resistance to insulin or bleeding (NAGAO; SATA, 2010; SCULLY; FELIX, 2005). These individuals require immediate treatment and continuous monitoring, since the oral health can interfere with eating and the administration of medications, as well as the quality of life of these individuals (SANDERS et al., 2009).

Taking into consideration the facts above discussed, the aim of this study was to investigate the satisfaction with dental care of HCV infected patients assisted in a Brazilian public reference center for diagnosis and treatment of Hepatitis C.

\section{MATERIAL AND METHODS}

\section{Study design and setting}

This is a cross-sectional and descriptive study. HCV chronic patients and healthy population from Uberlandia City, Minas Gerais State, Brazil were targeted for the study. Individuals were recruited at the Ambulatory of Chronic Liver Pathologies of Clinics Hospital of University of Uberlândia (UFU), Minas Gerais State, Brazil. This institution is a reference center for liver disease diagnosis in Minas Gerais State and receives 190 $\mathrm{HCV}$ infected individuals per year. However, 109 individuals were not using any type of medication. The individuals of non-infected group were recruited in the hospital's waiting room.

\section{Study sample}

Sample size of HCV infected patients (n) was calculated according to a probabilistic model considering finite population and confidence level of 5\%. The estimated number of sample was 85 $\mathrm{HCV}$ infected patients. By employing convenience sampling method, 85 non-infected were targeted to study.

The study was conducted from February to December 2014. All individuals aged 18 years and above, with no physical and mental mutilation, not using any type of medication were included in the study.

In $\mathrm{HCV}$ infected group, it was included individuals carrier chronic Hepatitis $\mathrm{C}$, diagnosed through clinical and laboratorial exams.

The selection of patients occurred earlier than the invitation to participate in the research, analyzing the systemic records of patients with scheduled appointments at the ambulatory, in the same period of data collection. The individuals of non-infected group were randomly recruited in the central room of hospital waiting and they had features similar to population.

Exclusion criteria for $\mathrm{HCV}$ infected group were absence of informed consent or the presence of cognitive disturbs. For non-infected group, in addition to the two aspects above mentioned, the presence of any kind of disease was also a reason for dismissal.

\section{Data Collection}

All participants were personally interviewed and answered questions elaborated only for this study, regarding social and demographic characteristics (age, gender, ethnicity, education level, occupation, marital status, family income); risk factors for $\mathrm{HCV}$ infection (sexual orientation, number of sexual partners, condom usage); and questions about the last dental consultation (date, cause, oral health orientation, use and satisfaction with dental care in public or private service).

Prior the application of the instrument, it was performed a pilot study aiming to adequate the questionnaire before its definitive use. The pilot study included $20 \%(\mathrm{n}=11)$ of the definitive sample, and these individuals were not included in the final sample.

$\mathrm{HCV}$ infected patients were interviewed at the ambulatory, in the day of their medical scheduled appointments. People who accompanied the infected patients and were non-infected by HCV were approached randomly at the waiting room of Hospital of UFU and were invited to participate of 
the research. All interviews were done individually and privately.

\section{Statistical Analysis}

The descriptive analyses were performed to characterize the population through measures of central tendency (simple frequencies, mean) and measures of dispersion (standard deviation).

The tested hypothesis was that ratios of some variables were similar among the groups; the hypothesis was rejected if p-value was lower than 0.050 , which means the existence of difference between ratios.

Variables selected for their relevance and statistical significance $(\mathrm{P}<0.10)$ in the bivariate analysis were entered into the logistic regression model. The $95 \%$ confidence intervals $(95 \% \mathrm{CI})$ of the estimated odds ratio (OR) were also calculated, and a P-value $<0.05$ was considered statistically significant.

The analysis was performed using Statistical Packege for the Social Sciences (SPSS for Windows, Release 20.0; SPSS, Chicago, IL).

\section{Ethical aspects}

Table 1. Numerical and perceptual distributions of answers of participants regarding social and demographic characteristics and the risk factors of participants, according to the group. Brazil. 2015.

\begin{tabular}{|c|c|c|c|c|c|c|}
\hline \multirow[t]{2}{*}{ Variables } & \multicolumn{2}{|c|}{$\begin{array}{l}\text { HCV infected } \\
\text { Group }\end{array}$} & \multicolumn{2}{|c|}{$\begin{array}{l}\text { Non-infected } \\
\text { Group }\end{array}$} & \multicolumn{2}{|c|}{ Total } \\
\hline & $\mathbf{n}$ & $\%$ & $\mathbf{n}$ & $\%$ & $\mathbf{n}$ & $\%$ \\
\hline \multicolumn{7}{|l|}{ Gender } \\
\hline Male & 51 & 60 & 50 & 58.8 & 101 & 59.4 \\
\hline Female & 34 & 40 & 35 & 41.2 & 69 & 40.6 \\
\hline \multicolumn{7}{|l|}{ Ethinicity } \\
\hline Caucasian & 59 & 69.4 & 62 & 72.9 & 121 & 71.2 \\
\hline Other race or ethnicity & 26 & 30.6 & 23 & 27.0 & 49 & 28.9 \\
\hline \multicolumn{7}{|l|}{ Age (years) } \\
\hline 18 to 40 & 19 & 22.4 & 21 & 24.7 & 40 & 23.5 \\
\hline 41 to 50 & 22 & 25.9 & 16 & 18.8 & 38 & 22.4 \\
\hline 51 to 60 & 24 & 28.2 & 23 & 27.1 & 47 & 27.6 \\
\hline$>60$ & 20 & 23.5 & 25 & 29.4 & 45 & 26.5 \\
\hline \multicolumn{7}{|l|}{ Civil status } \\
\hline Married & 49 & 57.6 & 47 & 56.0 & 96 & 56.8 \\
\hline Single & 21 & 24.7 & 18 & 21.4 & 39 & 23.1 \\
\hline Widower/Widow & 9 & 10.6 & 11 & 13.1 & 20 & 11.8 \\
\hline Divorced & 6 & 7.1 & 8 & 9.5 & 14 & 8.3 \\
\hline \multicolumn{7}{|l|}{ Occupation } \\
\hline Employed & 40 & 47.1 & 52 & 61.2 & 92 & 54.1 \\
\hline Unemployed & 11 & 12.9 & 10 & 11.8 & 21 & 12.4 \\
\hline Retired & 25 & 29.4 & 18 & 21.2 & 43 & 25.3 \\
\hline
\end{tabular}




\begin{tabular}{lrrrrrr} 
Alone & 13 & 15.3 & 11 & 12.9 & 24 & 14.1 \\
Partner & 20 & 23.5 & 19 & 22.4 & 39 & 22.9 \\
Parter and children & 18 & 21.2 & 33 & 38.8 & 51 & 30.0 \\
Children & 18 & 21.2 & 13 & 15.3 & 31 & 18.2 \\
Other & 16 & 18.8 & 9 & 10.6 & 25 & 14.7 \\
Sexual Orientation & & & & & & \\
$\quad$ Homosexual & 3 & 3.5 & 3 & 3.5 & 6 & 3.5 \\
Heterosexual & 79 & 92.9 & 82 & 96.5 & 161 & 94.7 \\
$\quad$ Bissexual & 3 & 3.5 & - & - & 3 & 1.8 \\
$\quad$ Number of sexual partners & & & & & & \\
None & 15 & 17.6 & 15 & 17.6 & 30 & 17.6 \\
One & 60 & 70.6 & 53 & 62.4 & 113 & 66.5 \\
Two or more & 9 & 10.6 & 16 & 18.8 & 25 & 14.7 \\
No answer & 1 & 1.2 & 1 & 1.2 & 2 & 1.2 \\
Condom use & & & & & & \\
Yes & 19 & 22.6 & 12 & 14.3 & 31 & 18.4 \\
No & 65 & 77.4 & 72 & 85.7 & 137 & 81.6 \\
\hline
\end{tabular}

Regarding sexual orientation, $92.9 \%(\mathrm{n}=79)$ of HCV infected group and $96.5 \%(n=161)$ of the non-infected group were heterosexual. Most of both groups (infected: 70.6\% - $\mathrm{n}=60$; non-infected: $62.4 \%-n=53$ ) had one regular partner and reported not using condom during sexual intercourse (infected: $76 \%$ - $n=65$; non-infected: $84.7 \%$ - $n=72$ ).

Statistical analysis showed the variables: education level $(\mathrm{p}=0.001)$ and family income
GARBIN, C. A. S. et al.

$(\mathrm{p}=0.008)$ statistically significant, as showed in Table 2. The Ratio Test pointed that HCV infected group had a higher percentage of individuals with primary school $(\mathrm{p}=0.017)$. There was also a higher percentage of HVC infected individuals with family income between US\$250.10 to US\$500.20 $(\mathrm{p}=0.029)$. Non-infected group showed higher percentage of individuals with family income of US $\$ 787.8$ or more per month $(\mathrm{p}=0.002)$.

Table 2. Bivariate and multivariate analysis of study variables of participants according to the group. Brazil, 2015.

\begin{tabular}{|c|c|c|c|c|}
\hline Variables & $\begin{array}{l}\text { HCV infected Group } \\
\qquad(\mathbf{n}=\mathbf{8 5})\end{array}$ & $\begin{array}{c}\text { Non-infected Group } \\
(\mathbf{n}=\mathbf{8 5})\end{array}$ & $\begin{array}{c}\text { Bivariate } \\
\text { analysis } \\
\text { P valor } \\
\end{array}$ & $\begin{array}{c}\text { Multivariate } \\
\text { analysis }\end{array}$ \\
\hline Education level & & & \multirow{5}{*}{0.001} & \\
\hline Pre-School & 26 & 16 & & $3.065(0.851-11.041)$ \\
\hline Primary School & 22 & 9 & & $6.598(1.803-24.143)$ \\
\hline Secondary school & 30 & 38 & & $1.776(0.624-5.058)$ \\
\hline College & 7 & 22 & & 1.000 \\
\hline \multicolumn{5}{|l|}{ Family income } \\
\hline$<\operatorname{US} \$ 262.6$ & 4 & 4 & \multirow{3}{*}{0.008} & $1.14(0.199-6.518)$ \\
\hline US $\$ 262.6$ to US\$525.2 & 38 & 22 & & $1.955(0.754-5.073)$ \\
\hline US $\$ 525.2$ to US $\$ 787.8$ & 28 & 22 & & $1.721(0.683-4.334)$ \\
\hline $\begin{array}{l}>\text { US } \$ 787.8 \\
\text { Orientation about prevention } \\
\text { in oral health by dentist }\end{array}$ & 15 & 33 & & 1.000 \\
\hline Yes & 28 & 46 & \multirow{2}{*}{0.009} & 1.000 \\
\hline No & 54 & 39 & & $1.604(0.558-4.609)$ \\
\hline \multicolumn{5}{|l|}{ Satisfaction with dental care } \\
\hline Yes & 36 & 52 & \multirow{2}{*}{0.025} & 1.000 \\
\hline No & 46 & 33 & & $1.335(0.476-3.741)$ \\
\hline
\end{tabular}


Concerning last dental consultation, approximately $51.0 \%(n=43)$ of $\mathrm{HCV}$ infected group and $16.5 \%(n=14)$ of non-infected group reported less than 6 months elapsed since last consultation. Toothache was the most frequent reason which encouraged $23.5 \%(n=20)$ of $\mathrm{HCV}$ infected group and $35.3 \% \quad(n=30)$ of the non-infected group to dental appointment.

Only $23.5 \%(n=20)$ of HCV infected group and $29.4 \% \quad(n=25)$ of non-infected group were attended by a dentist in the public health services. On last dental appointment, 32.9\% $(n=28)$ of HCV infected group and $54.1 \%(n=46)$ of non-infected group were instructed about prevention in oral health by dentists. Regarding satisfaction of individuals with dental services, $42.4 \%(n=36)$ of $\mathrm{HCV}$ infected group and $61.2 \%(\mathrm{n}=52)$ of noninfected group were pleased (Table 3 ).

Table 3. Numerical and perceptual distributions of answers of participants regarding last dental consultation. Brazil. 2015.

\begin{tabular}{|c|c|c|c|c|c|c|}
\hline & \multicolumn{2}{|c|}{$\begin{array}{l}\text { HCV infected } \\
\text { Group }\end{array}$} & \multicolumn{2}{|c|}{$\begin{array}{l}\text { Non-infected } \\
\text { Group }\end{array}$} & \multicolumn{2}{|c|}{ Total } \\
\hline & n & $\%$ & n & $\%$ & $\mathbf{n}$ & $\%$ \\
\hline \multicolumn{7}{|l|}{$\begin{array}{l}\text { Time elapsed since last } \\
\text { consultation }\end{array}$} \\
\hline Had never consulted a dentist & 3 & 3.6 & $*$ & * & 3 & 1.8 \\
\hline Less than 6 months ago & 43 & 51.8 & 14 & 16.5 & 57 & 34.0 \\
\hline Less than 1 year ago & 13 & 15.6 & 17 & 20.0 & 30 & 17.8 \\
\hline More than 1 year ago & 7 & 8.5 & 26 & 30.6 & 33 & 19.6 \\
\hline More than 2 years ago & 10 & 12.0 & 11 & 12.9 & 21 & 12.5 \\
\hline More than 3 years ago & 7 & 8.5 & 17 & 20.0 & 24 & 14.3 \\
\hline \multicolumn{7}{|l|}{ Reason for dental consultation } \\
\hline Had never consulted a dentist & 3 & 3.5 & $*$ & * & 3 & 1.8 \\
\hline Toothache & 20 & 23.5 & 30 & 35.3 & 50 & 29.4 \\
\hline Routine visit & 34 & 40.0 & 47 & 55.3 & 81 & 47.6 \\
\hline Other & 28 & 32.9 & 8 & 9.4 & 36 & 21.2 \\
\hline \multicolumn{7}{|l|}{ Type of dental service } \\
\hline Had never consulted a dentist & 3 & 3.5 & * & * & 3 & 1.8 \\
\hline Private & 52 & 61.2 & 45 & 52.9 & 97 & 57.1 \\
\hline Public & 20 & 23.5 & 25 & 29.4 & 45 & 26.5 \\
\hline Odontologic insurance & 10 & 11.8 & 15 & 17.6 & 25 & 14.7 \\
\hline \multicolumn{7}{|c|}{$\begin{array}{l}\text { Orientation about oral health by } \\
\text { dentist }\end{array}$} \\
\hline Had never consulted a dentist & 3 & 3.5 & $*$ & * & 3 & 1.8 \\
\hline Yes & 28 & 32.9 & 46 & 54.1 & 74 & 43.5 \\
\hline No & 54 & 63.5 & 39 & 45.9 & 93 & 54.7 \\
\hline \multicolumn{7}{|c|}{ Satisfaction with dental services } \\
\hline Had never consulted a dentist & 3 & 3.5 & $*$ & * & 3 & 1.8 \\
\hline Yes & 36 & 42.4 & 52 & 61.2 & 88 & 51.8 \\
\hline No & 46 & 54.1 & 33 & 38.8 & 79 & 46.5 \\
\hline
\end{tabular}

Variables in Table 2 showed significant statistical association according to Chi-squared Test: Time elapsed since last appointment $(\mathrm{p}=0.000)$, reason for dental consultation $(\mathrm{p}=0.001)$, instructed about prevention in oral health $(\mathrm{p}=0.009)$ and satisfaction with the health service $(\mathrm{p}=0.025)$.

As for dental care, ratio test pointed: higher percentage of $\mathrm{HCV}$ infected group visited a dentist less than 6 months ago $(\mathrm{p}=0.000)$; higher percentage of non-infected group visited a dentist more than one year ago $(\mathrm{p}=0.001)$; in the $\mathrm{HCV}$ infected group, the main reason for visiting a dentist was "other reasons" $(\mathrm{p}=0.000)$, as prosthesis $(\mathrm{n}=17 ; 20.0 \%)$ and exodontia $(\mathrm{n}=5 ; 5.8 \%)$; higher percentage of $\mathrm{HCV}$ non-infected group were instructed about prevention in oral health $(\mathrm{p}=0.015)$ and were pleased with dental services $(\mathrm{p}=0.037)$.

The category "Secondary school", part of the variable education level, was significant, and 
was considered a risk factor for $\mathrm{HCV}$ infection (OR:6.598 [1.803-24.143]), as shown in Table 2.

\section{DISCUSSION}

Hepatitis $\mathrm{C}$ virus infection is a serious public health problem with different prevalence rates observed worldwide. In Latina America, the expected prevalence is $1.5 \%$ (ALVARADOMORA; PINHO, 2013; PEREIRA et al., 2013; SZABO et al., 2012). It means that 7.8 million of people are infected by HCV. In Brazil, prevalence of anti-HCV is $1.38 \%$ (BRAZIL, 2011). In face of the lack of data in scientific literature, this study aimed to characterize the patients infected by HCV and verify their satisfaction with dental care provided by a Brazilian public reference center, in comparison with the healthy population.

HCV infected group had lower family income and lower education level compared to the Non-Infected group as demonstrated by other studies performed in Brazil and around the world (DA SILVA et al., 2013; VILLAR et al., 2015; SZABO et al., 2012). Individuals who had low education level (primary school) also had a 6.598 times bigger risk of being infected by $\mathrm{HCV}$ than those who had higher education level (college school).

Hepatitis $\mathrm{C}$ is a stigmatized disease associated to illegal drugs use, HIV/AIDS and promiscuity (ZICKMUND et al., 2003). However, the results found show that most patients of $\mathrm{HCV}$ infected group had a stable relationship with a regular partner and only one sexual partner. Nonetheless, no condom use during last sexual intercourse was reported by $80.0 \%$ of them. Therefore, it is important to highlight there is risk of $\mathrm{HCV}$ infection through intercourse; even though it is small (ROONEY; GILSON, 1998). Educational actions are essential to encourage condom use.

Concerning Hepatitis C treatment, advances have been noticed through Brazil. The efficacy endpoint of antivirus therapy is the sustained virological response (SVR), defined as an undetectable HCV RNA load in serum with a sensitive assay $(<50 \mathrm{UI} / \mathrm{mL})$, measured 24 weeks after the end of treatment by polymerases chain reaction (PCR) (GHANY et al., 2011). In order to reduce the number of new cases, and the mortality and also to improve the quality of life of $\mathrm{HCV}$ infected patients, the government has been offering options of treatment according to the most recent scientific works (NAVEIRA et al., 2014). Currently, the treatment of hepatitis $\mathrm{C}$ offered by Brazilian Public Health System (SUS) is the combination of of pegylated interferon (PEG) ribavirin (RBV), telaprevir (TVR), boceprevir (BOC). Recently, daclatasvir has also been included among the medicines provided by the government (LAWITZ et al., 2012; NIH, 2002; ZEUZEM et al., 2011).

Over the last decades, easiness of the improving access to the medical care with the administration of those medicines has been important to control the disease (NAVEIRA et al., 2014). However, there is no study reporting the accessibility and satisfaction of $\mathrm{HCV}$ infected patients regarding dental service in Brazil or in the world.

According to the last Brazilian epidemiological survey, aproximately $20 \%$ of Brazilian adults at age of 35 to 74 had reported toothache over the last months, and the severity of pain was level 5 (31.3\%) (BRASIL, 2011). In this study, almost half of the HCV infected group was attended by a dentist over the last 6 months, after the diagnosis of hepatitis $\mathrm{C}$, and the pain was the main reason for the dental appointment. This shows that an important part of $\mathrm{HCV}$ infected patients and of the healthy population is attended by a dentist when dental disease is already in an advanced stage, which causes stress and/or pain. This situation could be avoided if the access to public dental services were expanded.

Despite the recognized importance of oral health, considerable portion of the Brazilian population, including $\mathrm{HCV}$ infected individuals, does not have access to free dental care (BRASIL, 2011). Among adults, inequalities on accessibility to dental services occur due to the following factors: social and demographic factors, importance attributed to oral health, anxiety, reduced accessibility to dental services and the lack of the need of dental care (FREEMAN, 1999; ROHR, BARCELLOS, 2008).

More than $74 \%$ of $\mathrm{HCV}$ infected individuals can develop extra-hepatic manifestation during the course of the disease and oral cavity can exhibit signs of liver problems in the form of various disorders and/or diseases, such as lichen planus, blood disorders, sialadentitis; for this reason, in order to manage these individuals during dental treatment, it is important that dentists know about the main aspects of $\mathrm{HCV}$, like prevention, diagnosis, transmission, natural history of disease and symptoms of the infection, which can be present in the oral cavities of hepatitis C-infected individuals. Whatever the stage of the liver disease, dentists must perform a thorough and accurate evaluation of the patient and should promote educational, 
prophylactic and oral health interventions (GARBIN et al., 2014; LODI et al., 2012).

Health education is an essential tool for the development of programs to obtain the improvement of oral health of the HCV infected individuals, as well as of general population. It is through health education that people construct ideas regarding the importance of oral health, promote the development of skills to maintain good oral health condition and, as a consequence it will help prevent oral diseases (GARBIN et al., 2012). For this reason, orientation about oral health, diet, the use of fluoride and the regular dental appointment with a dentist are essential to guarantee the oral health of $\mathrm{HCV}$ infected individuals, who need special care. However, only $33.0 \%$ of HCV infected individuals in this study reported being properly oriented about prevention in oral health in the last dental appointment with a dentist.

The index of use of dental services is considered an indicator of access to dental services (ROHR; BARCELLOS, 2008). HCV infected patients had limited access to the public dental services, maybe due to barriers which must be identified and eliminated to improve the efficiency of the organization of health services.

The access to free dental care service must be efficient and able to satisfy the user of public health service. However, fewer than half of $\mathrm{HCV}$ infected individuals were pleased with their last dental appointment in public or private services. Enhancing access to free dental care services, aiming to ensure full, universal and satisfying assistance to the population is still a challenge in Brazil.

\section{CONCLUSIONS}

Education level was a risk factor to $\mathrm{HCV}$ infection indicating the necessity of education campaigns in this population in order to increase the knowledge about prevention and treatment of hepatitis C.

HCV infected patients showed low frequency of satisfaction with dental services. Thus, dental care programs aiming ensure patient satisfaction should be improved in the study region.

RESUMO: A infecção pelo vírus da hepatite C (HCV) é um problema de saúde pública mundial que afeta mais de 123 milhões de pessoas. Os indivíduos infectados com o HCV devem ter acesso aos serviços odontológicos, mesmo aqueles que são candidatos a transplantes hepáticos ou que estão submetidos a tratamento. É importante garantir a satisfação dos indivíduos com o serviço odontológico oferecido. Objetivo: Caracterizar os pacientes infectados com o HCV e verificar a satisfação dos mesmos com o atendimento odontológico, em comparação com indivíduos não infectados. Metodologia: Este estudo transversal incluiu 170 participantes; 85 indivíduos infectados com HCV e 85 indivíduos sadios, que foram entrevistados sobre os fatores de risco, acesso e satisfação com o atendimento odontológico. Resultados: O grupo de infectados com o HCV apresentou nível de escolaridade mais baixo, sendo que apenas 30,6\% havia concluído a pré-escola. Em relação à orientação sexual, 70,6\% do grupo de infectados com o HCV era heterossexual, e, 92,9\% possuía um parceiro sexual. Sessenta e cinco indivíduos infectados com HCV $(77,4 \%)$ e 72 não infectados $(85,7 \%)$ relataram que não usavam preservativo. Quarenta e dois por cento do grupo de infectados com o HCV e 61,2\% do grupo de não infectados estavam satisfeitos com o serviço odontológico. $\mathrm{Na}$ análise multivariada, o nível de escolaridade foi considerado uma variável de risco. Conclusão: A escolaridade foi um fator de risco para infecção pelo HCV e os pacientes infectados apresentaram menor frequência de satisfação com os serviços odontológicos.

PALAVRAS-CHAVE: Hepacivirus. Hepatite C. Saúde bucal. Fatores de risco. Satisfação pessoal.

\section{REFERENCES}

ALVARADO-MORA, M. V.; PINHO, J. R. Epidemiological update of hepatitis B, C and delta in Latin America. Antivir Ther, London, v. 18, p. 429-33, jun., 2013. http://dx.doi.org/10.3851/IMP2595

ALTER, M. J. Epidemiology of hepatitis C virus infection. World J Gastroenterol, Beijing, v. 13, n. 17, p. 2436-412007, may., 2007. http://dx.doi.org/10.3748/wjg.v13.i17.2436

BRAZIL. Ministry of Health. SB Brasil 2010. Brazilian oral health survey. Main results. Brasília, Ministry of Health; 2011 (Portuguese). Available at:

http://bvsms.saude.gov.br/bvs/publicacoes/pesquisa_nacional_saude_bucal.pdf Acessed: May 26, 2015. 
BRAZIL. Ministry of Health. Viral hepatitis. 2011. Avaible at: http://www.aids.gov.br/sites/default/files/anexos/publicacao/2011/50073/boletim_hepatites2011_pdf_64874.pd f. Accessed July 01, 2012.

BRAZIL. Ministry of Health. Manual counseling viral hepatites. Brasília: Ministry of Health; 2005. Avaible at: http://bvsms.saude.gov.br/bvs/politicas/hepatites_aconselhamento.pdf Accessed July 01, 2012.

DA SILVA, N. M.; GERMANO, F. N.; MENDOZA-SASSI, R. A.; SEUÁNEZ, H. N., SOARES, M. A.; DE MARTINEZ, A. M. Evidence of association between hepatitis $C$ virus genotype $2 b$ and nosocomial transmissions in hemodialysis centers from southern Brazil. Virol J, Baltimore, n. 10, p. 167.

2013.http://dx.doi.org/10.1186/1743-422X-10-167

DOUGALL, A.; FISKE, J. Access to special care dentistry, part 5: safety. Br Dent J, London, v. 205, p. 17790, aug., 2008. http://dx.doi.org/10.1038/sj.bdj.2008.693

FEDERAL COUNCIL OF DENTISTRY. Code of Dentistry Ethics. Rio de Janeiro. 2012 (Portuguese).

FREEMAN, R. The psychology of dental patient care: Barriers to accessing dental care: patient factor. Br Dent J, London, v. 187, n. 3, p. 141-1444, aug., 1999.

GALOSSI, A.; GUARISCO, R.; BELLIS, L.; PUOTI, C. Extrahepatic manifestations of chronic HCV infection. J Gastrointestin Liver Dis, Cluj-Napoca, v. 16, n. 1, p. 65-73, mar., 2007.

GARBIN, C. A.; DE SOUZA, N. P.; DE VASCONCELOS, R. R.; GARBIN, A. J.; VILLAR, L. M. Hepatitis $\mathrm{C}$ virus and dental health workers: an update. Oral Health Prev Dent, New Malden, v. 12, n. 4, p. 313-321, dec., 2014. http://dx.doi.org/10.3290/j.ohpd.a32134.

GARBIN, C. A. S.; ROVIDA, T. A. S.; GARBIN, A. J. I.; ARCIERI, R. M.; SOUZA, N. P. DE; MOIMAZ, S.A.S. Oral health and early childhood education: evaluation of the wear and storage of toothbrushes used by preschoolers. Rev Odontol UNESP, v. 41, n. 2, p. 81-87, mar./apr., 2012.

GHANY, M. G.; NELSON, D. R.; STRADER, D. B.; THOMAS, D. L.; SEEFF, L.B. An update on treatment of genotype 1 chronic hepatitis $\mathrm{C}$ virus infection: 2011 practice guideline by the American Association for the Study of Liver Diseases. Hepatology, Baltimore, v. 54, n. 4, p. 1433-1444, oct., 2011.

http://dx.doi.org/10.1002/hep.24641

GREBELY, J.; DORE, G. J. What is killing people with hepatitis C virus infection? Semin Liver Dis, New York, v. 31, n. 4, p. 331-339, nov., 2011. http://dx.doi.org/10.1055/s-0031-1297922.

HAJARIZADEH, B.; GREBELY, J.; DORE, G. J. Epidemiology and natural history of HCV infection. Nat Rev Gastroenterol Hepatol, London, v. 10, n. 9, p. 553-562, sep., 2013. http://dx.doi.org/ 10.1038/nrgastro.2013

LAWITZ, E.; ZEUZEM, S.; NYBERG, L. M.; NELSON, D. R.; ROSSARO, L.; BALART, L. A. K.; REDDY, R.; MORGAN, T.; DENG, W., KOURY, K. J.; ALVES, K., DUTKO, F., WAHL, J.; PEDICONE L, POORDAD, F. Boceprevir (BOC) combined with peginterferon alfa-2b/ribavirin (P/RBV) in treatment-naïve chronic HCV genotype 1 patients with compensated cirrhosis: sustained virologic response (SVR) and safety subanalyses from the Anemia Management Study. Hepatology, Baltimore, v. 56, p. 216A, 2012.

LODI, G.; BEZ, C.; PORTER, S.R.; SCULLY, C. EPSTEIN JB. Infectious hepatitis C, hepatitis G,and TT virus: review and implications for dentists. Spec Care Dentist,Chicago, v. 22, n. 2, p. 53-58, mar., 2002. http://dx.doi.org/ 10.1111/j.1754-4505.2002.tb01162.x 
MOHD HANAFIAH, K.; GROEGER, J.; FLAXMAN, A. D.; WIERSMA, S. T. Global epidemiology of hepatitis $\mathrm{C}$ virus infection: new estimates of age-specific antibody to HCV seroprevalence. Hepatology, Baltimore, v. 57, n. 4, p. 1333-1342, apr., 2013. http://dx.doi.org/ 10.1002/hep.26141.

MOHSEN, A.; BERNIER, A.; LEFOULER, L.; DELAROCQUE-ASTAGNEAU, E.; EL-DALY, M.; ELKAFRAWY, S.; EL-MANGO, S.; ABDEL-HAMID, M.; GADALLAH, M.; ESMAT, G.; MOHAMED, M.K.; FONTANET, A. Hepatitis $C$ virus acquisition among Egyptians: analysis of a 10-year surveillance of acute hepatitis C. Trop Med Int Health, Oxford, v. 20, n. 1, p. 89-97, jan., 2015. http://dx.doi.org/ $10.1111 /$ tmi. 12410

NAGAO, Y.; SATA, M. Dental problems delaying the initiation of interferon therapy for HCV-infected patients. Virol J, London, v. 7, p. 192, aug., 2010. http://dx.doi.org/ 10.1186/1743-422X-7-192

NAVEIRA, M.; BARBOSA, J.; SERENO, L.; DOMANICO, A.; MESQUITA, F.; DE SOUZA, L.A. 12 years of universal access to hepatitis $C$ treatment: Brazil's comprehensive response. J Int Assoc Provid AIDS Care; Thousand Oaks, v. 13, n. 6, p. 560-5677, nov./dec., 2014. http://dx.doi.org/ 10.1177/2325957414547739

NIH. National Institutes of Health. Consensus Statement on Management of Hepatitis C: 2002. NIH Consens State Sci Statements;v. 19, n. 3,p. 1-46, jun., 2002.

QIU, J.; OZAWA , M.; TERASAKI, P. I. Liver transplantation in the United States. Clin Transpl, Los Angeles, p. 17-28, 2005.

PEREIRA, L. M.; MARTELLI, C. M.; MOREIRA, R. C.; MERCHAN-HAMMAN, E.; STEIN, A. T.; CARDOSO, M. R.; FIGUEIREDO, G. M.; MONTARROYOS, U. R.; BRAGA ,C.; TURCHI, M.D.; CORAL, G.; CRESPO, D.; LIMA, M. L.; ALENCAR, L. C.; COSTA, M.; DOS SANTOS, A. A.; XIMENES, R. A. Prevalence and risk factors of Hepatitis C virus infection in Brazil, 2005 through 2009: a cross-sectional study. BMC Infect Dis, v. 13, p. 60, feb., 2013. http://dx.doi.org/10.1186/1471-2334-13-60

ROHR, R. I. T.; BARCELLOS, L. A. Barriers on the access to dental services. UFES Rev Odontol, Vitória, v. 10, n. 3, p. 37-41, 2008.

ROONEY, G.; GILSON, R. J. Sexual transmission of hepatitis C virus infection. Sex Transm Infect, London, v. 74, p. 399-404, 1998.

SANDERS, A. E.; SLADE, G. D.; LIM, S.; REISINE, S. T. Impact of oral disease on quality of life in the US and Australian populations. Community Dent Oral Epidemiol, Copenhagen, v. 37, n. 2, p. 171-81, apr., 2009. http://dx.doi.org/ 10.1111/j.1600-0528.2008.00457.x.

SCULLY, C.; FELIX, D.H. Oral medicine: update for the dental practitioner: dry mouth and disorders of salivation. Br Dent J, London, v. 199, n. 7, p. 423-427, oct., 2005. http://dx.doi.org/10.1038/sj.bdj.4812740

STOOPLER, E. T.; SIA, Y. W.; CHALIAN, A. A.; O'MALLEY, B. W. JR.; ALAWI, F. A rare presentation of multiple primary squamous cell carcinoma of the tongue in a patient with recurrent hepatitis $\mathrm{C}$ infection. Spec Care Dentist, Chicago, v. 34, n. 2, p. 96-99, mar./apr., 2014. http://dx.doi.org /10.1111/scd.12030

SZABO, S. M.; BIBBY, M.; YUAN, Y.; DONATO, B. M.; JIMÉNEZ-MENDEZ, R.; CASTAÑEDAHERNÁNDEZ, G.; RODRÍGUEZ-TORRES, M.; LEVY, A.R.The epidemiologic burden of hepatitis C virus infection in Latin America. Ann Hepatol, Mexico, v. 11, n. 5, p. 623-635, sep./oct., 2012. 
ZEUZEM, S.; ANDREONE, P.; POL, S.; LAWITZ, E.; DIAGO, M.; ROBERTS, S.; FOCACCIA, R.; YOUNOSSI, Z.; FOSTER, G.R.; HORBAN, A.; FERENCI, P.; NEVENS, F.; MÜLLHAUPT, B.; POCKROS, P.; TERG, R.; SHOUVAL, D.; VAN HOEK, B.; WEILAND, O.; VAN HEESWIJK, R.; DE MEYER, S.; LUO, D.; BOOGAERTS, G.; POLO, R.; PICCHIO, G.; BEUMONT, M. Telaprevir for retreatment of HCV infection. N Engl J Med, Boston, v. 364, n. 25, p. 2417-2428, jun., 2011.

http://dx.doi.org/10.1056/NEJMoa1013086

ZICKMUND, S.; HO, E. Y.; MASUDA, M.; IPPOLITO, L.; LABRECQUE, D. R. "They treated me like a leper". Stigmatization and the quality of life of patients with hepatitis C. J Gen Intern Med, Secaucus, v. 18, n. 10, p. 835-44, oct., 2003. http://dx.doi.org /10.1046/j.1525-1497.2003.20826.x

VILLAR, L. M.; SOUZA, N. P.; MOIMAZ, S. A. S.; GARBIN, A. J. I.; BORGES, A. S. B.; GARBIN, C. A. S. Epidemiological profile of Hepatitis $C$ virus infection in patients from West Region of Minas Gerais State, Brazil. Biosci. J., Uberlândia, v. 31, n. 2, mar./apr., 2015. http://dx.doi.org/10.14393/BJ-v31n2a2015-26538. 